\title{
"ACORDA POVO QUE O GALO CANTOU": UMA EXPRESSÃO CULTURAL NA PERIFERIA DO RECIFE
}

\author{
Carlos André Silva de Moura ${ }^{1}$ \\ Mário Ribeiro dos Santos ${ }^{2}$ \\ Sandra Simone Moraes de Araújo ${ }^{3}$
}

\section{Introdução}

A cidade é um livro texto que se deixa desnudar pelo narrador. Este ao mesmo tempo que olha, conta-lhe segredos, repete discursos.

Maria Aparecida Nogueira

Perceber a cidade como um texto, cujo conteúdo é construído a partir das infinitas narrativas dos seus moradores ou dos indivíduos que por ela simplesmente transitam, é um exercício praticado pelos componentes do Grupo de Pesquisa Histórias das Religiões e Práticas Culturais, do Campus Mata Norte da Universidade de Pernambuco.

Nos estudos que realizamos, compreendemos que os narradores da cidade são todas as pessoas ou grupos que contam suas práticas, modos de vida, visões de mundo, memórias e histórias. Como observa Walter Benjamin, “o narrador retira da experiência o que ele conta: sua própria experiência ou a relatada pelos outros. E incorpora as coisas narradas às experiências dos seus ouvintes" (Benjamin, 1994:201).

Narrar é também "a faculdade de intercambiar experiências" (Benjamin, 1994:198). Neste sentido, este texto tem o objetivo de apresentar a narrativa sobre uma forma de expressão que ocorre há mais de 80 anos nos subúrbios do Recife e da Região Metropolitana, conhecida como Acorda Povo. Este evento acontece durante os festejos juninos e reúne música, dança, ancestralidade e devoção a São João e ao orixá Xangô, como um meio de difundir as produções culturais existentes na periferia, as quais potencializam os saberes e os fazeres de grupos que não são reconhecidos e validados pelas narrativas hegemônicas.

\footnotetext{
${ }^{1}$ Universidade de Pernambuco - UPE Campus Mata Norte, Brasil. E-mail: carlos.andre@upe.br. ORCID: https://orcid.org/0000-0002-5584-1398

${ }^{2}$ Universidade de Pernambuco - UPE Campus Mata Norte, Brasil. E-mail: mario.santos@upe.br. ORCID: https://orcid.org/0000-0002-9319-9877

${ }^{3}$ Universidade de Pernambuco - UPE Campus Mata Norte, Brasil. E-mail: sandra.araujo@upe.br. ORCID: http://orcid.org/0000-0001-7923-2194
} 
O estado de Pernambuco, juntamente com a Bahia, o Maranhão, o Rio de Janeiro e o Rio Grande do Sul constitui um dos principais polos de cultura e religiosidade afrobrasileira do país. Pernambuco, por sua vez, tem na história da sua formação uma íntima relação com o processo escravagista que sustentou a economia açucareira da capitania durante séculos. No período colonial da nossa história, povos africanos, entre eles bantus e sudaneses, desembarcaram em nossos portos na condição de escravizados e trouxeram consigo as suas práticas culturais, o conhecimento de variadas técnicas de produção agrícola, artesanal e tecnológica, diversas línguas, crenças, entre outros saberes e fazeres historicamente negados e invisibilizados. $\mathrm{O}$ reflexo dessa africanização dos costumes resistiu no tempo e pode ser identificado nas periferias da cidade do Recife, onde habita, em sua maioria, a população negra e faz morada a sua produção cultural nos seus múltiplos aspectos.

É desse lugar de atuação repleto de adversidades, que as formas de expressão e celebrações afro-brasileiras invadem as cidades pernambucanas nos diversos momentos festivos do ano, reinventando-se para existir, resistir e garantir o protagonismo da população negra na produção cotidiana do conhecimento. Os Maracatus Nação, as Escolas de Samba, os Afoxés, os grupos de Acorda Povo, de Hip-Hop, de Capoeira, de Reggae, entre outras manifestações das culturas afro-diaspóricas são alguns exemplos de movimentos negros que desde a sua formação atuaram e fizeram política por meio das expressões culturais ${ }^{4}$.

Nesse sentido, com o intuito de democratizar o acesso à forma de pensar as culturas negras e dar visibilidade à diversidade de sentidos presentes nas práticas cotidianas das periferias do Recife, apresentamos essa reflexão sobre os grupos de Acorda Povo. Para isso, problematizamos questões étnico-raciais até então vistas sem importância pelas narrativas oficiais, ocasionando uma lacuna considerável nos registros históricos referentes às expressões das culturas populares.

Adotamos uma metodologia de trabalho, que nos colocasse em contato diretamente com as trajetórias individuais e coletivas dos agentes envolvidos com os grupos em estudo, no intuito de compreender e interpretar as diferentes realidades vivenciadas. $\mathrm{O}$ contato empírico com os agentes do bem cultural se desenvolve nos bairros de Areias, Várzea, Chão de Estrelas, no Recife; e em Olinda, nas comunidades de Sapucaia de

\footnotetext{
${ }^{4}$ Para aprofundar a temática sobre as expressões culturais negras em Pernambuco, Cf. SILVA, Claudilene da (Org.). Recife Nação Africana: catálogo da cultura afro-brasileira. Recife: Fundação de Cultura Cidade do Recife, 2008.
} 
Dentro e Amaro Branco. Esse diálogo é importante e necessário para nos aproximar das subjetividades, dos ritos, das músicas e dos elementos de comunicação artesanalmente construídos, a exemplo dos andores, das bandeiras, das estrelas, entre outros códigos criados que ultrapassam a dimensão material, plástica e sonora da forma de expressão em estudo.

O recorte para este trabalho diz respeito às experiências apreendidas no contato com Dona Nenzinha e seus familiares, consanguíneos e de santo, no período que antecedeu os preparativos até a realização do Acorda Povo da Vila das Lavadeiras, no bairro de Areias, Zona Oeste do Recife. O fato de selecionar o referido grupo não nos impede de dialogar com outras experiências de grupos diferentes. O Acorda Povo de Dona Nenzinha constitui o grupo mais antigo em atuação na cidade e mantém um modelo de organização que o singulariza diante dos outros grupos existentes.

Partindo desse pressuposto, optamos por analisar a referida manifestação no intuito de entender o que a prática significa para as lideranças e os seus seguidores; como se dá a devoção ao orixá e ao santo católico; e quais os rituais religiosos que antecedem a saída do cortejo pelas ruas da comunidade.

\section{As interfaces entre o Xangô, as festas de São João e as práticas culturais afro- brasileiras no Acorda Povo}

Os primeiros intelectuais a se interessarem pelo registro do Acorda Povo foram os folcloristas. O nosso objetivo com este trabalho é apresentar uma nova leitura sobre o tema, para lançar mão de mais uma contribuição sobre o assunto, a partir das narrativas das pessoas envolvidas na produção e execução dessa manifestação cultural, problematizando questões naturalizadas, que foram repetidas a ponto de inculcar nas mentes que o Acorda Povo tinha uma mesma origem e um único sentido para todos os agentes envolvidos.

Mas afinal, o que é um Acorda Povo? Por que ele é vivenciado no período das festas juninas, preterido em relação às comemorações cristãs e encontrado nos subúrbios da cidade durante a madrugada? O Acorda Povo é uma forma de expressão viva nas festas juninas da Região Metropolitana do Recife, uma realidade orgânica, que tem cheiro de vida e uma dinâmica própria. Foi gestada por diferentes segmentos étnicos, que aqui chegaram e criaram maneiras de estar no mundo. Novos símbolos, novas formas de comer, de cantar, de dançar, de rezar, de louvar e de agradecer. Um conjunto 
de práticas com múltiplas cores, texturas, sabores e sons, que flutua entre o presente e o passado, não se resumindo ao tempo em que vivem.

Acordar, no contexto da forma de expressão analisada, é a possibilidade de recomeçar. É o despertar para o novo amanhecer. É a oportunidade de renovar o significado das tradições. "Acorda Povo que o Galo Cantou", diz a toada cantada em uníssono convidando o povo para o convívio, para experienciar a festa e a devoção ao orixá e ao santo precursor do Messias.

Na manifestação, Xangô e São João são invocados para dar proteção, para presenciar sua festa celebrada num percurso de vários caminhos, onde famílias e histórias se cruzam, passando umas pelas outras; intercambiando num só espaço: música, dança, ancestralidade e devoção.

É nesse universo marcado pela diversidade que identificamos a manifestação do Acorda Povo, prática cultural que reflete a mistura das expressões de religiosidades de determinados grupos de africanos e europeus que se entrecruzaram durante o processo de colonização, marcado por uma realidade de violências, perseguições, extermínios, resistências e relações de poder entre diferentes povos e culturas.

De algumas regiões da África ocidental herdamos modelos de cultos a divindades conhecidas no Brasil como orixás, principalmente Xangô - o terceiro Alafin (Rei) de Oyó - uma das cidades da Nigéria. Em Pernambuco, a palavra Xangô adquiriu sentidos variados: pode significar um segmento da religião afro-brasileira, uma das divindades do panteão africano e remeter ao nome da casa onde se realizam os cultos.

Do contato com os colonizadores portugueses conhecemos as tradições de celebrar os santos católicos, aqui apropriadas e reelaboradas. Essas apropriações culturais negam a pureza e a autenticidade que algumas lideranças das diferentes religiões que existem no Brasil defendem, por não aceitarem essas misturas, que continuam se fazendo (Moura; Costa; Silva, 2020).

Essa disponibilidade para mesclar culturas é descrita pelo historiador João José Reis (1996) como um imperativo de sobrevivência dos povos escravizados, um exercício de sabedoria, também refletida na habilidade de compor alianças sociais, as quais inevitavelmente se traduziam em transformações e interpenetrações culturais.

Diante desse contexto histórico que brotava, surgiram formas de comunicação, receitas, outros modos de vestir, de diversão, espaços de sociabilidade, novas traduções do sagrado, orações, cânticos, festas, entre outras formas de expressão e celebrações 
desenvolvidas e ressignificadas em um cotidiano notadamente plural, a exemplo dos banhos noturnos em homenagem a São João.

\section{Os banhos noturnos em homenagem a São João e as aproximações com o Acorda Povo}

Um dos primeiros intelectuais a se debruçar no tema das festas juninas em Pernambuco foi Pereira da Costa, recifense nascido no bairro de Santo Antônio. Em 1851, quando ainda era jovem, despertou o interesse pela leitura de temas da história e do folclore da região. Hábil pesquisador, frequentador assíduo dos arquivos estaduais e eclesiásticos, bom observador, anotava o que lia, via e ouvia falar durante as conversas com os mais velhos.

Em 1908, publicou o livro Folk-lore Pernambucano: subsídios para a história da poesia popular em Pernambuco, no qual reúne informações sobre superstições, brinquedos infantis, poesias, romances, quadras populares, entre outros assuntos coletados em textos bibliográficos, manuscritos, jornais e entrevistas com diferentes pessoas.

Trouxemos para este trabalho, as práticas registradas pelo autor sobre as noites de junho em tempos de Colônia, quando era comum nos dias dedicados a São João, principalmente nos festejos do campo, encontrar "ranchos de homens e mulheres, coroados de capelas de flores e folhas, percorrendo alegres as estradas e ruas dos povoados." De acordo com o pesquisador, as pessoas enfeitadas com as capelas, "na abençoada noite", iam ao "milagroso banho", cantando os "conhecidíssimos versos: Capelinha de melão / É de São João / É de cravos, é de rosas / É de manjericão" (Costa, 2004: 200).

No Recife, os capelistas percorriam em animados bandos as ruas próximas ao porto e “encaminhavam-se, de preferência, para o banho na Cruz do Patrão, no istmo de Olinda, cujas águas, quer as do mar, de um lado, quer as do rio Beberibe, do outro, gozavam na noite de São João da particular virtude de dar felicidades e venturas" (Costa, 2004: 201).

Tomar banhos na madrugada que antecede o dia do nascimento de São João significava para os devotos purificar-se, dissolver os males, curar as tristezas, desintegrar as enfermidades, afastar a falta de amor, o desemprego e outras "mazelas" que atrapalhavam o desenrolar da vida das pessoas. Outro significado atribuído ao banho nas águas do rio, riacho ou mar, nas vésperas do dia do santo era também uma 
alusão ao batismo de Cristo nas águas do Rio Jordão. Em todos os sentidos, o que compreendemos é que o ato simbólico do banho é, portanto, o início de um novo ciclo, uma nova vida, agora regenerada, limpa, pronta para recomeçar (Eliade, 2008).

A prática do banho de São João se desloca no tempo e continua nas primeiras décadas do século XX, integrando a programação dos festejos do Estado. As matérias abaixo do Diário de Pernambuco de junho de 1946 ilustram essa realidade: a primeira faz referência a dois modelos de comemoração, um voltado para as elites da cidade, realizada em clubes fechados com entrada mediante pagamento de ingresso, compra de mesas, geralmente destinadas aos associados. O segundo tipo de comemoração apresenta uma proposta mais aberta, organizada pelos moradores da comunidade, com rodas de coco, samba e outros ritmos populares. Compondo essa programação popular, encontra-se o banho de São João:

\begin{abstract}
As comemorações em louvor do Batista assumirão, este ano, em Olinda, animação sem precedentes nas tradições dos nossos festejos joaninos. A nota de elegância dessas festividades será dada pelo Clube Atlântico, onde será realizado na noite do dia 23, uma reunião dansante de caráter acentuadamente regional [...] Na praça João Lapa, moradores e comerciantes estão se agrupando numa grande comissão que irá promover vários entretenimentos naquele local. Do programa em organização contam dansas, cocos e sambas ao ar livre, fogueiras e fogos de artifício. No dia 23, às 23 horas, sairá uma "barca" para Duarte Coelho, onde se realizará o tradicional banho da noite de $\mathrm{S}$. João. Exceto quanto à barca, os demais números do programa serão cumpridos nos dias 12, 13, 23, 24, 27, 28 e 29 do corrente em louvor de Santo Antônio, S. João e S. Pedro (Diário de Pernambuco, 1946).

Em Salgadinho e na Ilha do Maruim, haverá comemorações das datas consagradas a Santo Antônio, São João e São Pedro, constando de banhos, cocos, sambas e dansas. Na noite do dia 23, do sitio da Mangabeira, sairá às 23 horas para os Arrombados, o tradicional banho com a barca simbólica e marujos recrutados entre os moradores (Diário de Pernambuco, 1946).
\end{abstract}

Observamos na documentação que a caminhada em procissão dos devotos até o rio mais próximo da comunidade onde residem é chamada de "barca" pelos participantes e os devotos do santo batizados de "marujos", "recrutados entre os moradores da cidade". Todo o percurso seguia animado por danças embaladas pelos ritmos do coco e do samba.

Atualmente, as lembranças da infância da Mestra de Coco Ana Lúcia de Amaro Branco, nascida em 1944, aproxima-se desse contexto que relaciona o banho de São João aos momentos festivos com dança, música e muitos pedidos de bênçãos pelos devotos:

Meu pai já fazia o banho de São João. O Acorda Povo ia para o rio, só que não existe mais rio. Você não pode se jogar ali dentro pra tomar um banho que tá 
contaminado, muito sujo, mas o rio era tudo limpo e tinha pouca casa. Eu nasci aqui, isso era mato e as casas distante. E levava [os participantes do acorda povo para tomar banho de rio] lá pra Casa Caiada, levava pra Rio Doce. Saía cantando, fazia o côco. Aí saía cantando pra levar o andor com a bandeira para o rio. Quando chegava no rio, arriava a bandeira, o andor, todo mundo mergulhava, as pessoas de idade faziam os seus pedidos, as pessoas novas era [pedido de] casamento. E depois que terminava isso tudinho, o pessoal saía cantando com a procissão. Meu pai já deixava antes de sair de casa, pamonha, canjica, milho cozinhado, tudo, mais umas mesas que pareciam uns balcões enormes (Ana Lúcia, 2018). ${ }^{5}$

Em outro depoimento sobre o Acorda Povo, concedido pela mestra cirandeira e representante das Bandeiras de São João e São Pedro, Cristina Andrade, aponta aproximações entre o formato do cortejo (o qual ela denomina de procissão) e a prática do banho citada por Ana Lúcia com ritos presentes na religião dos orixás. Segundo a entrevistada, na ocasião: "saía o povo em forma de procissão, com batuque tocando e vai até a beira do rio se banhar, cantando as músicas de São João que eu não sei, com manjericão que benze o povo. Isso é coisa que sai do Xangô" (Cristina Andrade).

É importante ressaltar que esse processo de aproximação entre o Acorda Povo e o Candomblé não se deu à parte dos acontecimentos históricos, mas de maneira articulada e conjunta com as condições que aqui chegaram os diferentes grupos étnicos africanos, trazidos na condição de escravos para o Brasil. De acordo com o pesquisador Kabengele Munanga, "a deportação dos africanos e a imposição do regime escravista acarretaram um processo de ressignificação mítico-religiosa e de atribuição de outros e novos significados às coisas e ao mundo que nos rodeiam, por parte dos nossos ancestrais com suas divindades e crenças" (Munanga, 2006:140)

É nesse contexto de reinvenção das práticas culturais, no intuito de dar continuidade às suas diversas experiências religiosas no Novo Mundo, que em Pernambuco as comemorações para o orixá Xangô ganham popularidade entre os adeptos do Candomblé no mesmo período das festas em homenagem a São João. Essa relação, talvez seja pelo fato de haver aproximações de alguns símbolos comuns às duas divindades, a exemplo do elemento fogo presente nas fogueiras acesas em louvor ao santo e ao orixá.

Esse caráter festivo do Acorda Povo ressaltado nas falas de Cristina Andrade e Ana Lúcia se aproxima da concepção de festa da antropóloga Rita Amaral. Para a autora, no

\footnotetext{
${ }^{5}$ Mestra Ana Lúcia - Acorda Povo de Amaro Branco, Olinda-PE. Entrevista realizada para a Pesquisa sobre o Acorda Povo e as Bandeiras dos Santos Juninos. Olinda, 11 de junho de 2018. Acervo FUNDARPE.
} 
Candomblé, a dança, a música e a alegria são afirmações do sagrado, assim como o ato de confraternizar, que potencializa os laços de fraternidade entre os adeptos:

A ideia de que a vida é festa marca de modo profundo a visão de mundo do povo de santo e é perceptível também fora da religião. [...] Assim, o povo de santo será visto no candomblé, mas também nos afoxés, nas escolas de samba, nos pagodes, [...] na capoeira, nos shows de música afro e em várias outras atividades ligadas à festa de um modo ou de outro (Amaral, 1993:02).

O entendimento do conceito de festa para os povos do Candomblé também dialoga com o pensamento da pesquisadora Claudilene Silva, quando afirma que o "espaço da cultura é considerado um dos lugares privilegiados para a atuação dos negros no Brasil. Historicamente, este espaço tem sido de grande importância para a manutenção da sobrevivência e resistência desse povo" (Silva, 2008:7). É nesse sentido, que o Acorda Povo se aproxima intimamente dos terreiros de Candomblé, uma vez que foram os povos de terreiro fazendo uso do calendário festivo católico, que salvaguardaram as comemorações ao orixá Xangô entrecruzando com as celebrações a São João Batista.

Num dos registros do pesquisador Evandro Rabello é destacado que o Acorda Povo “é, talvez, a derradeira procissão religiosa do Brasil, onde, com a presença do povo, ainda se dança" (Diário de Pernambuco, 1975). Neste momento, dançar para o santo ou orixá é se fazer mais próximo a eles, faz parte do sacramento e da relação de devoção estabelecida entre o santo, o orixá e o devoto. Uma prática herdada do Candomblé e do tipo de catolicismo que se propagou pelas colônias portuguesas no Brasil, sobretudo, entre os populares, na qual os devotos se comunicavam com o sagrado por caminhos mais concretos, visíveis e palpáveis, a exemplo de festas, procissões dançantes, fogos de artifício, fogueiras, comidas, bandeiras estampadas com as imagens dos santos e altares montados no interior das casas barrocamente ornamentados com velas e flores distribuídas nas cores do santo.

Essa intimidade estabelecida entre a divindade e os devotos nos remete a uma das toadas cantadas durante os cortejos. Nos versos que embalam os seguidores nas ruas, São João cai n'água com as donzelas, num momento de confraternização e alegria que envolvia o ato festivo: "São João foi tomar banho. Com vinte e cinco donzelas. As donzelas caíram n'água. São João caiu com elas”.

Só mesmo na nossa forma singular de devoção aos santos que São João cairia na água com vinte e cinco donzelas, tomado de grande animação. Essas imbricações envolvendo religiosidade, momentos de riso e euforia nos impossibilita de estabelecer 


\section{Carlos André Silva de Moura, Mário Ribeiro dos Santos e Sandra Simone Moraes de}

Araújo

fronteiras que delimitam até onde vai o sagrado no interior dessas práticas culturais. Onde está a linha divisória que estabelece limites que confrontam esses dois lados? Será mesmo que existe essa relação dicotômica ou elas se misturam e imbricam-se de tal maneira que não conseguimos definir onde começa um e termina o outro? Sem respostas para essas inquietações, inferimos que manifestar a sua fé é um ato totalmente subjetivo, que para uns pode se resumir ao recolhimento num ambiente silencioso, mas para outros, quanto mais festa fizer, mais irá demonstrar o seu respeito e admiração pela divindade.

As relações dos grupos de Acorda Povo e as práticas do Candomblé, advém dessas alianças, revelando variados tipos e situações. De acordo com Ferretti, características “muito presentes na religiosidade, nas procissões, nas comemorações dos santos, nas diversas formas de pagamento de promessas, nas festas populares em geral, como em diversos elementos da religião oficial, por exemplo, no Catolicismo" (Ferretti, 2007:112).

A manifestação cultural Acorda Povo traz elementos dessas relações e apresenta como uma das suas especificidades o caráter festivo adotado pelos fiéis durante as homenagens ao santo e ao orixá. Essa forma de manifestar a devoção ao santo por meio da dança e da música será condenada e perseguida pela Igreja, num período conhecido como Romanização, iniciado na segunda metade do século XIX, quando a Igreja Católica na tentativa de pôr fim às práticas domésticas dos cultos, institui modelos de como os devotos deveriam reverenciar os seus santos de devoção (Moura, 2018). Esse tipo de normativa não será seguido piamente pelos populares, que no interior de seus lares e entre os seus pares, principalmente em regiões afastadas da vigilância da Igreja, encontraram "mil maneiras de caça não autorizada" pelo sistema, para dar continuidade às suas práticas (Certeau, 2007:38).

É nesse contexto de reação às normativas estabelecidas pelo sistema, que em 1941, a lavadeira, dona de casa e devota de São João, Adalgisa Marques de Almeida, Dona Dida, organizou com outros devotos uma procissão dançante em homenagem ao seu santo de devoção. O cortejo saía pelas ruas do bairro de Santo Amaro acordando o povo na madrugada do dia 23 de junho.

Essas práticas de religiosidade nas madrugadas dos subúrbios do Recife constituem o que Michel de Certeau chama de "movimentos contraditórios que se compensam e se combinam fora do poder panóptico" (Certeau, 2007:174). São as táticas do "homem 
ordinário", as "práticas microbianas", as astúcias, os "poderes sem identidade". (Certeau, 2007:174-175)

Dona Dida também acreditava na força dos orixás. Ela era adepta do Candomblé e frequentava o Sítio de Pai Adão - o terreiro mais antigo em funcionamento do Recife, desde o século XIX, localizado na Estrada Velha de Água Fria, Zona Norte da cidade. Uma religiosidade impregnada de sentidos, viva nas práticas do cotidiano, dentro de casa, na relação com o seu esposo (Antônio Marques de Almeida), sua filha (Aurelina Marques de Almeida), seus familiares, vizinhos e amigos.

No período da Interventoria de Agamenon Magalhães em Pernambuco (19371945), vilas operárias foram construídas nas regiões periféricas da cidade, fruto da política nacional de higienização e modernização dos centros urbanos (Santos, 2018). É nesse contexto que Dona Dida chega na Vila das Lavadeiras, levando para a nova localidade antigas formas de sociabilidade comemoradas no coletivo.

Aurelina Marques de Almeida cresceu diante da dupla devoção da sua mãe entre os santos da Igreja Católica e os orixás do Candomblé. Aurelina tornou-se lavadeira, casou-se e teve três filhos: Clésiton José Genésio de Almeida (Kesinho), Edivanderqui José de Almeida (Vandinho) e Claudineide Almeida da Silva (Neide). Lavava e engomava para os comerciantes de Areias e bairros próximos. Tornou-se conhecida como Dona Nenzinha, transformou-se numa liderança comunitária, religiosa e consagrou-se filha de Xangô - orixá dono de sua cabeça e principal protetor da sua vida:

\footnotetext{
Minha ligação é com meu pai Xangô, que merece, é referência a ele. Xangô é tudo na minha vida, é meu pai, num momento é meu filho, é tudo, meu amor. Ele significa minha família, muito bom pra mim [...] Quando solta a giranda parece que ele incorporou em mim, me dá aquela vontade de chorar tão grande com aquela alegria que eu sinto (Dona Nenzinha).
}

Em meados dos anos 1970 com o falecimento de sua mãe, Dona Nenzinha interrompe a tradição do Acorda Povo na comunidade. Perde o prazer de festejar em público, de enfeitar a frente da casa com bandeirinhas, não tem vontade de dançar o coco, de preparar o munguzá, nem reunir a vizinhança solidária nos gestos, nas palavras, nos sentimentos e nas emoções de festejar Xangô e São João.

Sem entusiasmo para continuar e ainda não preparada para assumir os compromissos religiosos da manifestação, Dona Nenzinha decide passar o Acorda Povo 
aos cuidados de Dona Vanda, uma ilorixá do bairro da Mustardinha, amiga da família e seguidora da prática desde a sua chegada na Vila das Lavadeiras.

No início dos anos 1990, o Acorda Povo voltou para a residência de Dona Nenzinha, também sob os cuidados dos filhos já adultos, que se apropriaram da prática e deram continuidade à tradição. Segundo Kesinho, "quando o Acorda Povo retornou por aqui a gente fez a obrigação pra Xangô, quando foi na hora de Xangô sair, na hora que o Acorda Povo saiu, uma senhora baixou Xangô na praça, e ele dizendo que estava muito feliz de ter voltado, que aqui era o lugar dele").

A relação com a religiosidade é muito forte dentro da manifestação. O respeito e o cuidado das lideranças do Acorda Povo com os preceitos religiosos se fazem notar durante as falas dos entrevistados. O período entre o início do mês de junho, o dia que antecede a saída do cortejo no bairro até o último momento, quando se entrega o andor na casa da juíza do próximo ano, tudo é vivenciado sagradamente por Dona Nenzinha, seus familiares, alguns filhos de santo do terreiro que ela frequenta e pela ialorixá Terezinha Bulhões, responsável pelos trabalhos espirituais dedicados ao orixá Xangô: "bombo, que é tocado junto com o caracaxá no cortejo e na procissão, fica desde a noite de véspera até quase às 4 h do dia 23 no peji ${ }^{6}$ " (segundo Kesinho).

No momento da saída do Acorda Povo, às 4 horas da madrugada, os fogos acordam quem estava dormindo e reúne quem estava disperso nas proximidades da casa de Dona Nenzinha. De pés descalços ou calçados, os festeiros e devotos guiados pela luz de uma vela dentro de uma estrela confeccionada de plástico e arame, seguem o fluxo do cortejo embalados pelo som do bombo, do caracaxá e dos maracás. Devotos que rezam enquanto caminham; outros dançam enquanto cantam e uns cantam, dançam e rezam ao mesmo tempo.

As cores vermelho e branco predominam nas roupas e acessórios dos seguidores. Símbolos da identidade religiosa do catolicismo e do Candomblé são identificados: torsos, fios de conta, terços e contra eguns. As ruas parecem constituir verdadeiros prolongamentos dos terreiros e das igrejas, fazendo surgir uma "cidade estranha" ao espaço geometricamente projetado do centro funcionalista e conceitual (Certeau, 2007).

\footnotetext{
6 Lugar reservado para as devoções do terreiro, onde se encontram os assentamentos dos orixás, as insígnias, entre outros elementos sagrados.
} 
Os diferentes códigos criados pelos seguidores do Acorda Povo, para vivenciar as suas religiosidades durante a manifestação, constituem o que Michel de Certeau (2007) classifica como "procedimentos de caráter informal". Um conjunto de práticas adotado pelos festeiros católicos e filhos de santo como uma tática de fazer uso do lugar controlado pela Igreja, instituindo, contudo, novos espaços de circulação.

O cortejo segue o percurso previamente organizado por um dos filhos de Dona Nenzinha, atendendo ao pedido dos moradores do bairro pagadores de promessas. $\mathrm{Na}$ frente das casas desses devotos, o Acorda Povo saúda o dono, canta e aplaude a bandeira que é hasteada em sinal de agradecimento pela graça alcançada. Durante a passagem do Acorda Povo, ruas, becos e vielas da localidade transfiguram-se em territórios religiosos, estabelecendo novos sentidos e configurações à Vila das Lavadeiras. Esses lugares geográficos (casas, ruas e praças) que, cotidianamente são utilizados com funções rotineiras: residências, caminhos dos transeuntes ao trabalho, pontos de comércio e lazer, em determinado espaço-tempo adquirem outros significados, seja por meio de símbolos ou por meio das condutas dos indivíduos, sacralizando-os e fortalecendo assim as relações que dão origem a uma identidade religiosa e a um sentimento de pertencimento do grupo envolvido na manifestação cultural.

Vale ressaltar que esses espaços, ora sacralizados pelas práticas dos sujeitos, são também demarcados por esses agentes e obedecem a uma lógica própria de funcionamento, cujo objetivo é atender a dinâmica dos grupos de Acorda Povo. Dentro da perspectiva da sacralidade, o território é colocado como sendo uma dimensão simbólica, isso envolve necessariamente agentes que planejam, executam e experienciam as canções, as crenças, os rituais, entre outros valores, produzindo uma memória coletiva e, portanto, de identidade no tempo e no espaço.

Por volta das 5 h30 da manhã, com o céu claro, o Acorda Povo já tem encerrado o seu percurso e retorna para a casa da matriarca, onde é levantada a última bandeira. É hora de dançar o coco, comer munguzá, bolo de milho, amendoim e beber fartamente em homenagem a São João e a Xangô. O que se come e o que se bebe no Acorda Povo são receitas que nos chegam experimentadas por diferentes gerações.

Tradicionalmente, o munguzá de milho amarelo é o mais consumido. Cada família tem um jeito próprio de prepará-lo. Pode ser servido só com canela, mas também acrescido de outros temperos a exemplo do cravo e da erva-doce. Para beber, a tradição 
do quentão e do licor ou vinho de jenipapo passa de família para família. Há aquelas que dão um toque especial na receita, mas a base da bebida permanece a cachaça, fundamental para aquecer os festeiros e devotos nas madrugadas frias de junho.

Outras iguarias derivadas do milho também fazem parte do banquete da noite: bolos, canjica, pamonha e o próprio milho em espigas cozidas e assadas. São receitas experimentadas por gerações, como parte integrante das histórias de cada família. $\mathrm{O}$ depoimento, a seguir, da Mestra de Coco Ana Lúcia de Amaro Branco ressalta a preocupação dos organizadores da festa em promover uma celebração farta para seus convidados:

\begin{abstract}
Meu pai já deixava antes de sair de casa, pamonha, canjica, milho cozinhado, tudo, mais umas mesas que pareciam uns balcões enormes. Tudo isso, milho cozinhado, pamonha, o vinho de jenipapo, que era sagrado, cerveja não existia, que a cerveja era pra rico. Não tinha refrigerante, era suco para as pessoas que não bebiam cachaça. Agora realmente era a cachaça, era diferentes das pitús, vinho de jenipapo era tradição, batida de cajá, batida de jenipapo, tudo tinha, eram das frutas que as pessoas tinham no quintal (Ana Lúcia).
\end{abstract}

Esse momento de distribuição da comida durante a festa adquire uma importância simbólica significativa para os devotos. Faz parte da promessa ao santo e ao orixá o oferecimento da comida aos amigos, aos vizinhos e aos familiares que seguiram pelas ruas em procissão para homenagear São João e Xangô. Esse momento da partilha também significa a celebração para o renascimento coletivo de um novo tempo que acabara de começar.

No Candomblé, nesta época do ano, é preparado um farto banquete para os orixás, em especial Xangô, celebrado com muita fartura e alegria pelos membros do terreiro. Alguns pratos são produzidos à base de milho e coco, como bolos e mungunzás; outros compostos de quiabo, camarão seco, azeite de dendê, carnes, gengibres, mel, entre outros ingredientes. Nesse conjunto de iguarias de origem africana e ressignificadas nas cozinhas dos terreiros pernambucanos, destacam-se o amalá e o biguiri como os principais pratos servidos a Xangô. O primeiro é feito basicamente com quiabo, castanha, amendoim, camarão e carne bovina, fartamente regado com azeite de dendê, temperado com pimenta, sal, cebola e cebolinha. Já o biguiri consiste numa espécie de papa feita com farinha de mandioca e água.

Vale ressaltar que os sentidos do cardápio votivo não estão apenas na sua produção e no consumo, mas sim na escolha dos ingredientes, no modo como são preparados e, principalmente, nas circunstâncias de sua consumação. É neste sentido, que a produção dos alimentos na cozinha da casa sagrada é um importante momento de sociabilidade e 
demonstração de fé, uma vez que os alimentos são ofertados com finalidades variadas, seja para satisfazer os desejos dos orixás, agradecer as bênçãos e os pedidos alcançados pelos devotos assim como estreitar os laços entre as divindades e os fiéis.

No que se refere à dança, o coco de roda constitui o carro chefe do Acorda Povo. No grupo de Dona Nenzinha, a chegada do cortejo em sua casa é comemorada com uma animada roda de coco que segue pelas primeiras horas do dia. Essa dança manifesta-se muito em trocas de "desafios" entre duplas, que fazem referência às danças de umbigadas, ao samba de roda, ao samba de partido alto e ao jongo, todas danças de influência predominantemente afro-brasileira. Ainda é a população negra moradora dos subúrbios e das periferias das cidades, ligada às religiões de matrizes africanas, que é a maior agente produtora do coco.

Por volta das 9 horas da manhã, o grupo que acompanhou todo o cortejo, desde a madrugada, começa a dispersar e retorna (agora em menor quantidade) às 19 horas do mesmo dia, para buscar o andor na casa da juíza da festa, responsável por guardar a imagem de São João de um ano para o outro. O andor volta enfeitado para a casa de Dona Nenzinha, o qual é recebido com rezas, cânticos e velas até o dia seguinte, 24 de junho. Liderado pela matriarca, o cortejo refaz o percurso da madrugada, arriando as bandeiras que foram levantadas nas casas dos devotos e seguem em procissão até a casa da nova juíza. O ritual se renova mais uma vez, garantindo a continuidade da tradição nos festejos de junho no Recife.

Partindo desse pressuposto, podemos identificar como os moradores dos bairros periféricos do Recife se articulam socialmente para organizar suas festividades, como fazem uso dos diferentes espaços e como vivenciam as suas religiosidades. São espaços produtores de novos conceitos e conhecimentos, não necessariamente produzidos pela academia, mas pelos saberes de pessoas como Dona Nenzinha da Vila das Lavadeiras, a Mestra Ana Lúcia de Amaro Branco, Cristina Andrade de Água Fria, entre outros agentes produtores de manifestações culturais no Estado.

Grande parte do que foi escrito neste texto foi possível por realizarmos um trabalho de campo juntos aos integrantes do Acorda Povo, cujo período envolveu as entrevistas, a observação participante, realizadas no período de 12 meses. É importante salientar o protagonismo de Dona Nenzinha na salvaguarda dessa manifestação. A liderança da Vila das Lavadeiras é detentora de um conhecimento chamado na academia de "saber privado", aquele saber carregado de "investimentos simbólicos relativos à vida 
cotidiana" (Certeau, 2007:142), que durante muito tempo não teve legitimidade no âmbito da universidade.

Quando Dona Nenzinha fala sobre o passado e nos apresenta o processo de deslocamento da sua mãe do centro da cidade para o subúrbio, relatando o desenvolvimento da localidade e apresentando os moradores e suas práticas culturais, ela também está interpretando o passado. Esse debate não é recente. Nos anos 1970, já se discutia sobre os métodos de pesquisa participante, fundamentados no diálogo entre os sujeitos não-cientistas (autores de práticas e expressões que traduzem o que sentem) e os detentores dos padrões e códigos dominantes do conhecimento científico.

O grupo de Acorda Povo analisado não apenas salvaguarda as manifestações culturais do período junino em Pernambuco, mas também garante a ocupação dos espaços da festa pelos sujeitos historicamente excluídos. Por intermédio dessa forma de expressão, formado na sua maioria por pessoas negras e moradores da periferia, os seguidores do Xangô se afirmam enquanto sujeitos dos seus contextos culturais.

Nesse sentido, a relação entre as práticas do Estado e as manifestações culturais vivenciadas nas periferias, nos diferentes contextos, marcados por perseguições, prisões, decretos cerceadores, entre outros mecanismos que buscavam desqualificar os momentos de diversão dos populares, resistiram e hoje os saberes dos que praticam o Acorda Povo é uma maneira de fortalecer a história de um lugar. Como considera Circe Bittencourt:

A história do "lugar" como objeto de estudo ganha necessariamente contornos temporais e espaciais. Não se trata, portanto, de proporem conteúdos escolares da história local, de entendê-los apenas na história do presente ou de determinado passado, mas de procurar identificar a dinâmica do lugar, as transformações do espaço, e articular esse processo às relações externas, a outros "lugares" (Bittencourt, 2018:150).

Partindo desse pressuposto, identificamos que o contato com os integrantes do Acorda Povo potencializou e transformou as nossas experiências de aprendizagem, estimulando a pesquisa nos subúrbios da cidade, com foco na valorização das narrativas como um meio de escrever a história que dão a ver os saberes e as experiências coletivas como potências das relações do cotidiano.

$\mathrm{Na}$ encruzilhada de saberes diversos, as festas juninas, universo macro onde vive, entre outras formas de expressão, o Acorda Povo só existe na coletividade, na pluralidade de saberes. Não se celebra sozinho. Festejamos em comunhão para rememorar feitos vividos, histórias de outros tempos com novos sentidos. 
Nesse sentido, este artigo devolve aos integrantes dos grupos de Acorda Povo, especialmente a Dona Nenzinha e seus familiares, o direito de ter suas histórias e memórias registradas por escrito e tornadas públicas. É uma forma de resistir contra a ideia da democracia racial, o racismo religioso e as diferentes formas de discriminação nas mais diversas dimensões.

Um momento oportuno para dar visibilidade as táticas cotidianas de negros e negras, moradores e moradoras das periferias do grande Recife que, sabiamente, recriaram os patrimônios herdados de seus antepassados em diálogo com os novos contextos históricos. Portanto, foi nossa opção ouvir quem faz acontecer a manifestação todos os anos. Mais uma vez, as expressões culturais se fizeram presentes como um mecanismo eficaz de resistência das culturas negras e para a escrita de novas versões da história da cultura afro-brasileira em Pernambuco.

Cada relato registrado representou o descortinar de um mundo real não exibido nos programas de televisão, não comentado publicamente pelas autoridades, não presente nos debates escolares nem nos livros didáticos. No entanto, vivo, dançante e acordado nas madrugadas e durante o dia daqueles e daquelas que não perderam a esperança de amanhã ver suas histórias valorizadas, incorporadas nos currículos e nos debates públicos, valorizando as suas vivências, as suas diferenças e as formas de ler os símbolos que dão sentidos às suas existências.

Esse estudo apontou para algumas direções, entre elas, a pluralidade de formas de expressão das culturas negras que dão um colorido a mais aos festejos juninos do Estado. Entre os vários temas abordados, a estreita relação entre o catolicismo e o Candomblé merece destaque e por isso um debate mais aprofundado que problematize assuntos como relações de poder, racismo, religiões, religiosidades, laicidade, entre outros temas caros e necessários para afirmar a construção de representações positivas e novos pensamentos qualificados sobre as culturas negras.

\section{Referências}

AMARAL, Rita. O tempo de festa é sempre. In. Travessia. Revista do Migrante n. 15, janeiro/abril, Centro de Estudos Migratórios - CEM, São Paulo, 1993.

BENJAMIN, Walter. Obras escolhidas: magia e técnica, arte e política. $7^{\mathrm{a}}$ ed. São Paulo. Brasiliense. 1994.

BITTENCOURT, Circe Maria Fernandes. Ensino de História: fundamentos e métodos. 5 ed. São Paulo: Cortez, 2018. 
CARREIRO, Gamaliel da Silva. FERRETTI, Sérgio Figueiredo. SANTOS, Lyndon de Araújo. SANTOS, Thiago Lima dos. (Orgs.). Todas as águas vão para o mar: poder, cultura e devoção nas religiões. São Luís. EDUFMA, 2013.

CERTEAU, Michel de. A invenção do cotidiano: 1. Artes de fazer. 13. ed. Petrópolis, RJ: Vozes, 2007.

COSTA, Francisco Augusto Pereira. Folk-lore Pernambucano: subsídios para a história da poesia popular em Pernambuco. 2 ed. - Recife: CEPE, 2004

DIÁRIO DE PERNAMBUCO. Edição, Recife, 18 de junho de 1975

ELIADE, Mircea. O sagrado e o profano: a essência das religiões. $2^{\mathrm{a}}$ ed. São Paulo. Martins Fontes, 2008.

FERRETTI, Sérgio F. Sincretismo e Religião na festa do Divino. In. Revista Anthropológicas, ano 11, vol. 18(2): 105-122 (2007)

FERRETTI, Sérgio F. Repensando o sincretismo. São Paulo: Edusp: Fapema,1995.

FERRETTI, Sérgio F. Sincretismos, amálgamas e correspondências simbólicas. In: CARREIRO, Gamaliel da Silva. FERRETTI, Sergio Figueiredo. SANTOS, Lyndon de Araújo. (Orgs.) Missa, Culto e Tambor: espaços da religião no Brasil. São Luís EDUFMA/FAPEMA, 2012. p. 281-293.

MOURA, Carlos André Silva de. Histórias Cruzadas: intelectuais no Brasil e em Portugal durante a Restauração Católica (1910-1942). ICS - Imprensa de Ciências Sociais, 2018.

MOURA, Carlos André Silva de et. al. Sociologia, Religiões e Modernidade: ensaios em homenagem a Roberto Motta. Recife: EDUPE, 2020.

MOURA, Carlos André Silva de. SANTOS, Mário Ribeiro dos (orgs.). Nos Arraiais da Memória 2: as quadrilhas juninas escrevem diferentes histórias. Recife: Fundação de Cultura Cidade do Recife, 2013.

MUNANGA, Kabengele; GOMES, Nilma Lino. O negro no Brasil de hoje. São Paulo. Global, 2006.

NOGUEIRA, Maria Aparecida Lopes. A cidade imaginada ou o imaginário da cidade. In História, ciências, saúde. Volume 1. Recife. Maguinhos. Mar-jun/1998. p. 115-123

PRANDI, Reginaldo. De africano a afro-brasileiro: etnia, identidade, religião. Revista USP, São Paulo, n. 46, p. 52-65, junho/agosto, 2000.

RABELLO, Evandro. Acorda Povo. Recife, Instituto Joaquim Nabuco de Pesquisas Sociais. Centro de Estudos Folclóricos, 1976.

REIS, João José. Quilombos e Revoltas Escravas no Brasil. Revista USP, São Paulo, n. 28, p.14-39, 1996. 
SANTOS, Mário Ribeiro dos. Noites Festivas de Junho: histórias e representações do São João do Recife (1910-1970). Recife: Editora da UFPE, 2018.

SANTOS, Mário Ribeiro dos. Nos Arraiais da Memória: as quadrilhas juninas escrevem diferentes histórias. Recife: Fundação de Cultura Cidade do Recife, 2010.

SANTOS, Mário Ribeiro dos. Trombones, Tambores, Repiques e Ganzás: a festa das agremiações carnavalescas nas ruas do Recife (1930-1945). Recife: SESC, 2010.

SANTOS, Mário Ribeiro dos. Cartilha Ciclo Junino 2008. Recife: Fundação de Cultura Cidade do Recife, 2008.

SILVA, Claudilene da (Org.). Recife Nação Africana: catálogo da cultura afrobrasileira. Recife: Fundação de Cultura Cidade do Recife, 2008.

Data de submissão: 28 de agosto de 2021

Data de publicação: 20 de dezembro de 2021 